\title{
The Masculinity of Rural Men and The Role of Social Media
}

\author{
Moh. Sabab Nashrulloh \\ Magister Student of Social and Political \\ Sciences Faculty \\ Universitas Airlangga \\ Surabaya, Indonesia \\ sababnash_unair@yahoo.com
}

\begin{abstract}
The distribution of social media in changing the perception of the masculinity of rural men is very big. Nowadays, rural men do not only spend their time at work but also at the gym center to have good body appearance. Rural men think that the body shape is an important start to gain attention to themselves and give impact to people perception about the masculinity. Fitness center is more identic with urban culture. Urban males go to the fitness center to shape their body because it is important in the public domain and also the public activity which does not use physical work. The different thing happens to many rural men which is their public activity lack of significance in appearance and most of them usually use the physical energy. It becomes the interesting case to understand the body image of rural men in doing bodybuilding in the fitness center for their body. This study uses the interpretive paradigm and qualitative approach, while in retrieving data is the in-depth interview. This study use phenomenology method with the theory of body by Maurice Morley Ponty. As the compliment, this study gives a concept about body image to see perception formed and relation with media social. This research was conducted at Dukun village, Gresik. The distribution of media social in forming a perception about the masculinity of rural men is actually influential. It is described in the interest of rural men who come to the fitness center. The masculinity that shows body which is built in the fitness center make the rural men practice the bodybuilding as like what they see in media social by their gadget. The process of body building that they do is one of the more existence, which is not all men get. They try to dominate their aim as a form the body that touches the world. Their aim to get an appreciation of their hard effort, easy to interest woman and different visual looking with other become the marvelous thing and they feel that it is the body that embraces the world
\end{abstract}

\section{Keywords—Media social, masculinity, rural men}

\section{INTRODUCTION}

The masculinity of men is often interpreted with visual appearance. The ideal visual appearance is universally interpreted through the body shape. The body is also a cultural medium that has a number of attributes and identities attached to it, such as masculine, strong, healthy etc. [1]. The muscle body shape of a man becomes the body shape coveted by a man in general. Lately, the phenomenon of bodybuilding is in demand by rural society at Dukun Village, Gresik district, Indonesia. The bodybuilding is often seen as a gym activity in the fitness center was once an activity that is identical with the urban community. It becomes interesting when how a rural man who performs the bodybuilding in a fitness center, sees the body image of himself in the events and environment.

The identity of masculinity is inseparable from the radar of public scrutiny and depends on a set of structures and institutions [2]. The development of a growing gymnasium in the village area is inseparable from the role of social media as one of the forms of information globalization. Human digital technology easily disseminates information with large space and time scales [3]. The development of social media that diffuses to shape the public perception more homogeneous in certain aspects. The assumptions about the ideal men in the village also began to change with the presence of social media. Rural men are now getting attracted to the muscle body shape with six-pack belly that is widely seen in social media.

Quite a lot of previous research discussed on the topic of masculinity, body image, metrosexual and anything related to men with various theories. As Novi Kurnia research in 2004 which discusses the representation of masculinity in an advertisement by using analysis of Micheal Foucault. In 2013 Aunadya Rosa and Dr. Muhammad Ghazali Bagus Ani Putra discusses the relationship between body image and metrosexual level in men with marital quality. Being a different matter from this research that offers a new discussion in understanding the body image of rural men against their bodies by doing the bodybuilding in the fitness center, the reality of masculinity that occurs in rural men with a theory that is rarely used in a study, i.e. The phenomenology of body by Maurice Marleau Ponty.

\section{RESEARCH METHOD}

This research was conducted at Dukun village, in Gresik, Indonesia. The research uses the interpretive paradigm with a qualitative approach and phenomenology research method. Researchers wanted to peel the body image of rural men against their bodies by doing the bodybuilding in the fitness center using the body's concepts of Maurice Morley Ponte. Body image of rural men body who are influenced by social media. The depiction of the ideal man who can rule the world as described by Ponty is inseparable from the male body shape in general perception. The concept of body image can't be separated from a person's perception of his body. Thompson mentioned body image factors as mass media, social comparison, and gender [4]. Slade in Banfield and McCabe view the body image as a representation of what the individual 
thinks about body shape, body size, and body condition that is influenced by historical, cultural and social, individual and biological factors that operate over different time spans [5].

Marleau Ponty explains perception as a consciousness, in a state of flux and not the autonomous role of what is absorbed from the world. Ponty phenomenology contains a dimension of perception that shows the superiority of the body as a global vehicle. The body is not the subject or the object in full, but the ambiguous way of existence that affects all forms of knowledge. Knowledge is only possible if we live it in the context of our connection and the world through the body. The purpose of Ponty's phenomenology is not to discover the essence of existence, but to understand the existence of being lived. It is understood only as a means to achieve that goal. The form of worldly presence through the body by motor action and perception [6].

\section{RESEARCH RESULTS}

The establishment of the fitness center in the village is a reflection of how the body shape is very important. Body perception for village men is inseparable from the role of social media as part of the current globalization. Perception about the body is increasingly homogeneous as a result of social media that always displays the muscle male image as the ideal man. Perceptions of rural men associated with a body image are not autonomous. The perception of rural men is inseparable from the role of mass media that deals with social, cultural, and biological aspects in a given time and space. Male masculinity is not a static thing but changes in structure and culture are determined. Masculinity in this modern era can be seen in social media that displays the body shape of a muscle man who is considered ideal. The masculinity that leads to urban male culture begins to affect rural men easily. Rural men with their gadgets can easily see examples and processes about bodybuilding and fitness center.

Rural men with an ideal body, they will find it easier to get what they want and doing anything will be easier. The many female friends, the environment that always praises and accepts, is a consciousness and a goal. Rural men are aware that going to a fitness center needs money and good results because of hard efforts. Not all men can do it and get it. Rural men in their perceptions still consider strong people to be black skin and reflect hard workers as the masculinity of classical rural men. The male image of the village informing his body is a form of existence to achieve respect in the village environment. Things in the village that are not easily obtained will be easier if the ideal body that they get in the fitness center.

\section{CONCLUSION}

The development of social media is very rapid in the modern era as it is today. The role of social media is able to make a new form and more homogeneous perception. Modern masculinity today it refers to the muscle body shape of a man. The impact of mass media development by diffusion and the influence of mass media have changed the perception of rural male image body about masculinity. They form their existence by doing the bodybuilding in the fitness center. An existence that is achieved to reach the objectives of hard-earned rewards, is easier to attract their opposite sex and got the different visual appearance. Rural men go to the fitness center has formed a materialized existence. It becomes a different matter and is more appreciated by the social environment and the body that can touch the world.

\section{REFERENCES}

[1] Ardhie Raditya. (The Sociology of the Body: Extending Theory for Applied Use) "Sosiologi Tubuh: Membentang Teori di Ranah Aplikasi". Yogyakarta: Kaukaba Dipantara; 2014. p. 206.

[2] Rowena chapman, Jonathan Rutherford (edt). (Male Order: Uncover Masculinity) "Male Order: Menguak maskulinitas". Yogyakarta: Jalasutras: 2014.

[3] Fidler R. (Mediamorphosa: Understanding New Media) "Mediamorfosis: Memahami Media Baru”. Yogyakarta: Bentang Budaya; 2003, p. 107.

[4] Thompson, K. J. "Body Image, Eating Disorders, and obesity: An Integrative Guide for Assessment and Treatment". Washington DC: American Psychological Association; 2000.

[5] Banfield, S. S., McCabe, M. P. "An Evaluation of the Costruct of body image". Adolescence. Vol. 37, No. 149, Summer; 2002. San Diego: Libra Publisher.

[6] Adian DG. (Introduction to Phenomenology) "Pengantar fenomenologi". Depok: Kukusan; 2010, p. 95-99 